\title{
INFLUENCE OF FOLLICULAR ABLATION DURING LACTATION ON POSTWEANING INTERVAL TO ESTRUS, OVULATION RATE, AND ENDOCRINE FUNCTION IN SOWS
}

\author{
N.M. Cox , J.D. Armstrong and J.H. Britt
}

\begin{abstract}
Duroc sows farrowed second litters in March and lactated $35 \pm 2$ days. At $36 \mathrm{hr}$ before weaning, electrocautery of follicles $\geq 3 \mathrm{~mm}$ in diameter $(n=8)$ or sham surgery $(n=5)$ was performed to test the hypothesis that ablation of medium-sized follicles would prolong the duration of postweaning anestrus. Number of follicles and diameters at surgery were: $1.3 \pm .6(>5 \mathrm{~mm}$ diameter $), 26 \pm 1(3$ to $5 \mathrm{~mm})$ and $>20(<3$ $\mathrm{mm}$ ). Blood samples were collected at $15 \mathrm{~min}$ intervals for $3 \mathrm{hr}$ beginning at $-12,0$, 12,60 and $96 \mathrm{hr}$ from weaning. Interval to estrus was $3.4 \pm .2$ days in seven of eight cauterized sows and $3.6 \pm .6$ days for sham-surgery sows. The remaining cauterized sow was anestrus at slaughter, 40 days after weaning. Number of corpora lutea and pregnancy rate were $15.8 \pm .6$ and $92 \%$, respectively, and were similar between shamsurgery and cauterized sows. Concentration of follicle stimulating hormone (FSH) at $12 \mathrm{hr}$ before weaning was greater in sows subjected to electrocautery than for shamsurgery sows, but FSH values were similar at other sampling times. Concentrations of estradiol were similar at all times for both treatment groups. Luteinizing hormone (LH) was higher $(P<.05)$ at $60 \mathrm{hr}$ in cauterized sows because of the onset of the preovulatory LH surge in one sow. We conclude that destruction of medium-sized ovarian follicles before weaning did not influence postweaning reproductive performance.
\end{abstract}

\section{INTRODUCTION}

Weaning removes the negative influences of suckling on gonadotropin secretion, and sows generally exhibit estrus and ovulate within 4 to 7 days $(1,2)$. During lactation there is continuous growth and atresia of ovarian follicles, but maximum follicular diameter $(4-6 \mathrm{~mm})$ is less than that observed after weaning $(3,4)$. We reported that number of follicles $<5 \mathrm{~mm}$ in diameter decreased from 82 at weaning to 43 at $60 \mathrm{hr}$ after weaning ( 35 day lactations), but number of 5 to $10 \mathrm{~mm}$ follicles increased from 12 to 27 during the same period (5).

Most studies have indicated that, after weaning, increases in gonadotropins cause follicular growth which results in elevated concentrations of circulating estrogens $(6,7,8,9)$. Increasing concentrations of estrogen in peripheral circulation appear to be the major trigger for the preovulatory surge of gonadotropins and subsequent ovulation $(5,10,11)$.

In sows which fail to return to estrus promptly after weaning, one or more of the progressive changes in pre- or post-weaning endocrine events apparently is altered, thus delaying or preventing subsequent estrus and ovulation. In the present experiment, we hypothesized that endocrine events promoting prompt return to estrus depend on the presence of medium-sized follicles $(4-6 \mathrm{~mm})$ prior to weaning. The objective of this study was to determine the effects of 
ablating follicles $\geq 3 \mathrm{~mm}$ in diameter $36 \mathrm{hr}$ before weaning on postweaning interval to estrus, ovulation rate and peripheral patterns of LH, FSH and estradiol in sows.

\section{MATERIALS AND METHODS}

Fourteen second parity Duroc sows weighing $176 \pm 10 \mathrm{~kg}$ and nursing 8.5 \pm .4 piglets were subjected to blood sampling and surgical procedures during March 1982. During the fifth week of lactation (33 \pm 2 days of lactation), an indwelling catheter was inserted into the vena cava of each sow. The catheter was inserted nonsurgically through a 12-gauge thin-wall needle and was then taped to the neck with elastic bandage. The free end of each catheter was concealed in a denim patch to prevent damage between sampling periods. Anesthesia was then induced with approximately $1.0 \mathrm{~g}$ thiopental administered via the catheter and maintained with methoxyflurane $(.5-1.0 \%)$ and oxygen ( 1 liter $/ \mathrm{min}$ ). Sows were selected randomly for electrocautery of follicles $\geq$ $3 \mathrm{~mm}$ diameter $(\mathrm{n}=8)$ or sham surgery, including manipulation of the ovaries $(n=6)$. Number and diameter of visible follicles were recorded, and then follicles were cauterized through the use of a surgical cautery unit. One control sow was omitted from the experiment because corpora lutea were present at surgery. Following surgery, sows were allowed to recover for approximately $6 \mathrm{hr}$ before being returned to individual pens $(1.5 \mathrm{by} 3.7 \mathrm{~m})$ with their litters. Litters were weaned $36 \mathrm{hr}$ after surgery. Beginning 2 days after weaning, sows were checked for estrus twice daily with a boar and were mated 12 and 24 hr after onset of estrus. Reproductive tracts were obtained at slaughter at approximately 40 days after mating.

To determine whether the sham surgical procedure and blood sampling affected onset of estrus and ovulation rate, eleven second parity Duroc sows had their litters weaned at the same time as experimental sows. These sows were mated and slaughtered at 40 days after mating for determination of numbers of corpora lutea and embryos.

Blood samples were obtained at $15 \mathrm{~min}$ intervals for $3 \mathrm{hr}$ beginning at -12 , $0,12,60$ and $96 \mathrm{hr}$ from weaning. Concentrations of LH and FSH were measured by radioimmunoassay procedures validated in this laboratory (6). Standard preparations of LH and FSH were LER 786-3 and LA3-c2, respectively. Concentrations of estradiol were assayed in single samples obtained at the beginning of each $3 \mathrm{hr}$ bleeding period using a validated radioimmunoassay (8) with antiserum provided by N.R. Mason (Eli Lilly).

All two-way comparisons between treatments for interval to estrus and numbers of follicles, corpora lutea and embryos were by Student's t test (14). Effects of treatment and time on concentrations of hormones were examined using general linear models (15). Models for the split-plot analyses of variance for LH and FSH included treatment, sow within treatment, hr from weaning, sample within hr, treatment by hr and sow within treatment by hr. The model for estradiol included treatment, sow within treatment, hr and hr by treatment. Where analysis indicated significant effects, means were separated by the method of LSD (15).

\section{RESULTS}

The population of visible follicles present on the ovaries before electrocautery was similar for both surgical groups (Table 1). After surgery, the two groups differed only in the number of follicles $\geq 3 \mathrm{~mm}$ because no attempt was made to ablate follicles $<3 \mathrm{~mm}$ in diameter. 
Table 1. Number of Surface Ovaruan follicles Present 36 Hr Before Weaning.

\begin{tabular}{lccc}
\hline & \multicolumn{3}{c}{ Diameter $(\mathrm{mm})$} \\
\cline { 2 - 4 } Treatment & $<3$ & 3 to 5 & $>5$ \\
\hline Control (Sham, $\mathrm{n}=5)$ & $>20$ & $28 \pm 3^{n}$ & $.8 \pm .6$ \\
Cauterized $(\mathrm{n}=8)$ & $>20$ & $26 \pm 5$ & $1.1 \pm .6$ \\
$\quad$ Before surgery & $>20$ & 0 & 0 \\
$\quad$ After surgery & & &
\end{tabular}

There were no treatment differences for postweaning reproductive characteristics (Table 2). All non-surgical controls, all sows subjected to sham surgery and seven of eight in the cauterized group exhibited estrus. The remaining cauterized sow was anestrus at slaughter 40 days after weaning. Conception rate and numbers of corpora lutea and embryos were similar among the treatment groups. One sow in the non-surgical control group did not exhibit estrus until 9 days after weaning. The average interval to estrus for the remaining 10 sows in that group was $3.9 \pm .3$ days.

Individual profiles of LH and FSH for one sham-surgery control sow and one sow subjected to electrocautery are in Figure 1. Analyses of variance indicated that the effects of samples within periods were not significant for LH or FSH, so average values are presented in Figure 2.

For concentrations of FSH, the treatment-by-time interaction was significant. The only period when concentrations of FSH were affected by follicular ablation was at -12 hr from weaning (Figure 2) when FSH was elevated in cauterized animals $(P<.05)$. For the remainder of the sampling periods, concentrations of FSH were similar between sham-surgery control and electrocauterized groups. A preovulatory surge in FSH was beginning at $60 \mathrm{hr}$ in one control sow.

Concentrations of $\mathrm{LH}$ were affected by hr from weaning $(\mathrm{P}<.05)$, but not by treatment. Concentrations of LH were highest during the bleeding period at $96 \mathrm{hr}$ after weaning, when preovulatory surges were occurring, and lowest at $-12,0$ and $12 \mathrm{hr}$ from weaning. The lower $\mathrm{LH}$ in cauterized animals at 60 $\mathrm{hr}$ is attributable to the preovulatory LH surge evident at $60 \mathrm{hr}$ in one control sow.

Concentrations of estradiol were not affected by treatment (Figure 2).

\section{DISCUSSION}

These results clearly indicate that ablation of follicles $\geq 3 \mathrm{~mm}$ in diameter at $36 \mathrm{hr}$ before weaning did not influence onset of estrus or affect numbers of corpora lutea or embryos. These results contrast with results from studies

TABle 2. Reproductive Performance of Sows

\begin{tabular}{|c|c|c|c|}
\hline \multirow[b]{2}{*}{ Item } & \multicolumn{3}{|c|}{ Experimental Group } \\
\hline & $\begin{array}{c}\text { Sham-surgical } \\
\text { control }\end{array}$ & $\begin{array}{c}\text { Cauterized } \\
\text { surgery }\end{array}$ & $\begin{array}{c}\text { Non-surgical } \\
\text { control } \\
\end{array}$ \\
\hline $\begin{array}{l}\text { No. of sows } \\
\text { No. in estrus }\end{array}$ & $\begin{array}{l}5 \\
5\end{array}$ & $\begin{array}{l}8 \\
7\end{array}$ & $\begin{array}{l}11 \\
11\end{array}$ \\
\hline $\begin{array}{l}\text { Days to estrus } \\
\text { after weaning } \\
\text { No. conceiving } \\
\text { Ovulation rate } \\
\text { No. of embryos } \\
\end{array}$ & $\begin{array}{l}3.6 \pm .6 \\
5 \\
16.4 \pm .7 \\
11.3 \pm .6 \\
\end{array}$ & $\begin{array}{r}3.4 \pm .2 \\
15.3 \pm .5 \\
10.9 \pm .6\end{array}$ & $\begin{array}{c}4.7 \pm .5 \\
9 \\
14.9 \pm .9 \\
10.8 \pm 1.1\end{array}$ \\
\hline
\end{tabular}

Mean \pm SEM

At approximately day $\mathbf{4 0}$ of pregnancy 

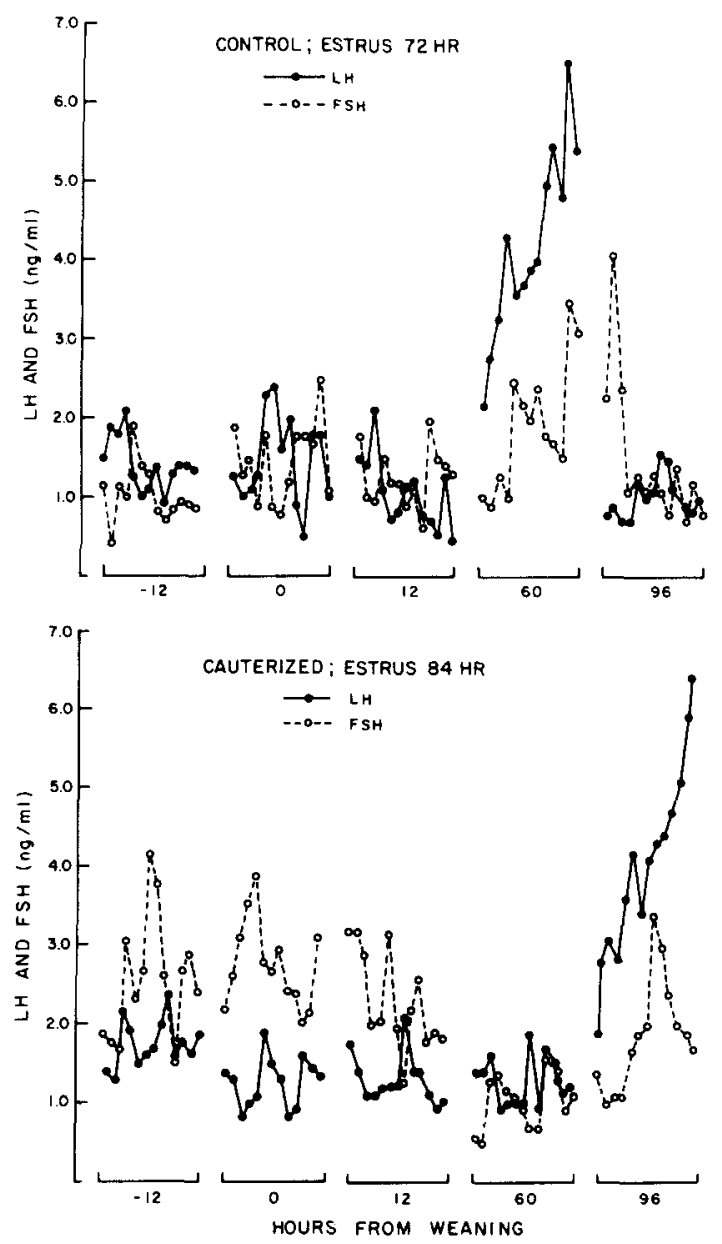

Fig. 1. Profiles of LH and FSH for one control (top panel) and one cauterized sow (bottom panel). Samples were taken at $15 \mathrm{~min}$ intervals for $3 \mathrm{hr}$ periods beginning $-12,0,12,60$ and $96 \mathrm{hr}$ from weaning.

on cycling gilts, in which cauterization of follicles resulted in delayed return to estrus (13) and a longer interval to development of preovulatory follicles (12). However, in those studies all visible surface follicles were removed (13), while in the present study only follicles at more advanced stages of development were destroyed.

The results of the present study could be interpreted two ways, either that 1) follicles $\geq 3 \mathrm{~mm}$ near the time of weaning are not the ones destined to ovulate at the postweaning estrus or that 2) elevated FSH evident $12 \mathrm{hr}$ before weaning permitted compensatory development of follicles remaining after electrocautery, so that interval to estrus was not delayed.

Although it has been reported that diameters of most follicles of lactating sows are $5 \mathrm{~mm}$ or less prior to weaning, $(3,16)$ little information is available on the size class of follicles which continue development to the ovulatory stage after weaning. In cyclic gilts, development of follicles after electrocautery of all visible surface follicles was fastest during the last third of the cycle (12). In that study, follicles 3 to $6 \mathrm{~mm}$ in diameter on day 14 in control gilts 

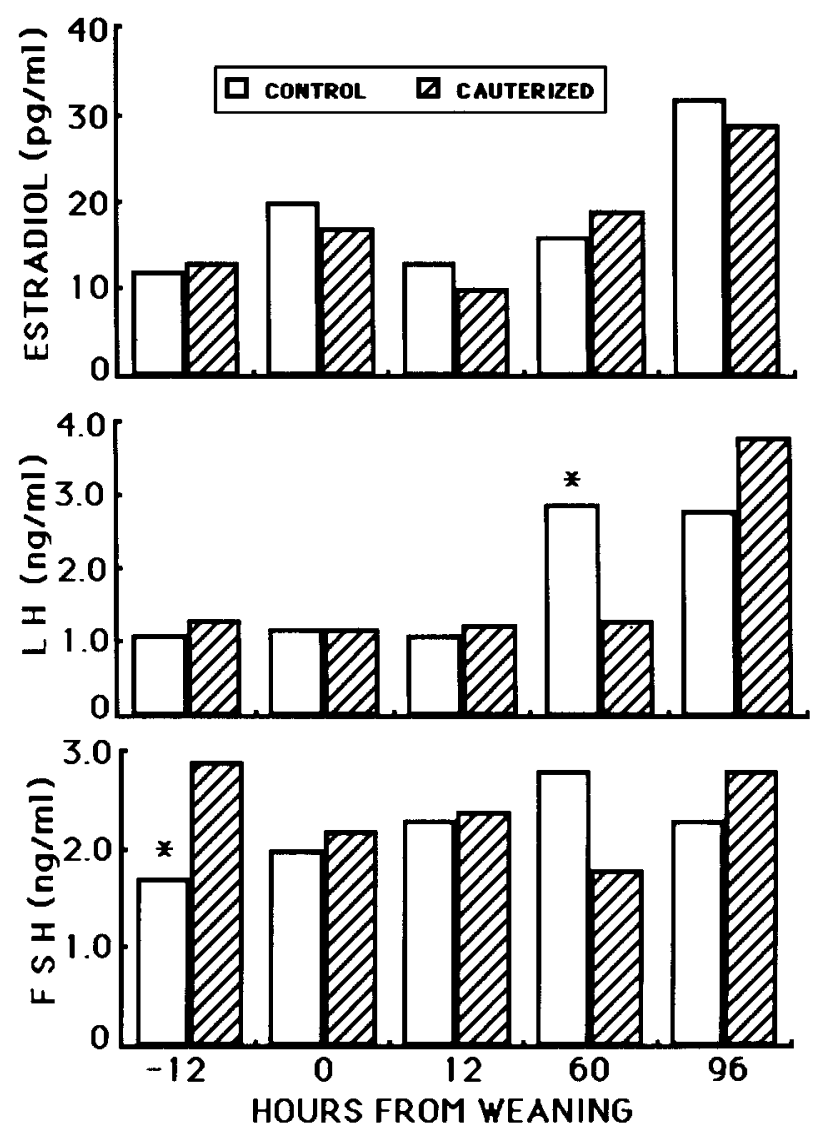

Fig. 2. Least squares mean concentrations of estradiol, LH and FSH at $-12,0,12,60$ and $96 \mathrm{hr}$ from weaning. For estradiol, each bar represents the mean of a single sample obtained at the beginning of the $3 \mathrm{hr}$ bleed period. For LH and FSH each bar represents the least squares mean for the bleeding period. Analysis of variance indicated that effects of sample (13 per period) within periods were not significant. Bars marked by an asterisk are different at the specified time.

were replaced by follicles 7 to $10 \mathrm{~mm}$ by day 20 of the estrous cycle. However, when gilts were subjected to electrocautery on day 14 , there were fewer follicles 7 to $10 \mathrm{~mm}$ and more follicles 3 to $6 \mathrm{~mm}$ on day 20 . If the growth of follicles from the 3 to $6 \mathrm{~mm}$ size category to preovulatory size (7 to 10 $\mathrm{mm}$ ) requires approximately 6 days $(12,13)$, it is possible that follicles cauterized in the present study were destined to ovulate after weaning (approximately 5 days from surgery to estrus) but were replaced by other follicles. If follicles $<3 \mathrm{~mm}$ in diameter at weaning develop to preovulatory size within 4 days, then development is faster in weaned sows than that reported for cyclic gilts. In cyclic gilts, rate of development of follicles depends on stage of the estrous cycle and is probably influenced by interactions between steroid hormones, particularly progesterone, and gonadotropins (12). For this reason caution should be used in extrapolating results with cyclic gilts to weaned sows, in which corpora lutea are not present prior to post-weaning estrus.

The only endocrine change apparently caused by electrocautery was the increased FSH evident at $12 \mathrm{hr}$ before weaning. The increase in FSH may have occurred earlier but was not detected because sampling did not begin until $24 \mathrm{hr}$ after surgery. The existence of an ovarian, nonsteroidal inhibitor of FSH 
secretion has been demonstrated previously for lactating sows $(6,17)$. The elevated FSH may have permitted compensatory growth of follicles $<3 \mathrm{~mm}$ in diameter remaining after electrocauterization. In this way, follicles of cauterized sows could have developed similarly to those of control sows by the time of weaning.

The failure of $\mathrm{LH}$ concentrations to change following electrocautery was expected. Concentrations of LH are maximally suppressed by nursing of piglets and increase following weaning, but not after ovariectomy during lactation $(6,10,11,18,19)$.

Overall, these results failed to support our hypothesis that destruction of follicles $\geq 3 \mathrm{~mm}$ in diameter before weaning would prolong the period of postweaning anestrus. The small follicles remaining after electrocautery were transiently exposed to greater concentrations of circulating FSH than follicles of sham-surgery sows. This increased FSH may have been sufficient to induce a brief compensation in follicular growth so that the postweaning interval to estrus and ovulation rate were indistinguishable from values observed in control sows.

\section{REFERENCES}

1. Self HL, Grummer RH. The rate and economy of pig gains and the reproductive behavior in sows when litters are weaned at 10 days, 21 days or 56 days of age. J Anim Sci 17:862-868, 1958.

2. Cole DJA, Varley MA, Hughes PE. Studies in sow reproduction. 2. The effect of lactation length on the subsequent reproductive performance of the sow. Anim Prod 20:401-406, 1975 .

3. Palmer WM, Teague HS, Venzke WG. Macroscopic observations on the reproductive tract of the sow during lactation and early postweaning. J Anim Sci 24:541-545, 1965.

4. Dyck GW. Postweaning changes in the reproductive tract of the sow. Can J Anim Sci 63:571-577, 1983.

5. Cox NM, Britt JH. Relationships berween endogenous gonadotropin-releasing hormone, gonadotropins and follicular development after weaning in sows. Biol Reprod 17:70-78, 1982.

6. Stevenson JS, Cox NM, Britt JH. Role of the ovary in controlling luteinizing hormone, follicle stimulating hormone, and prolactin secretion during and after lactation in pigs. Biol Reprod 24:341-353, 1981.

7. Edwards S, Foxcroft GR. Endocrine changes in sows weaned at two stages of lactation. J Reprod Fert 67:161-172, 1983.

8. Cox NM, Britt JH. Pulsatile administration of GnRH to lactating sows: Endocrine changes associated with induction of fertile estrus. Biol Reprod 27:1126-1137, 1982.

9. Kirkwood RN, Lapwood KR, Smith WC, Anderson IL. Plasma Concentrations of LH, prolactin, oestradiol-17 $\beta$ and progesterone in sows weaned after lactations of 10 or 35 days. J Reprod Fert 70:95-102, 1984. 
10. Cox NM, Esbenshade KI, Britt JH. Treatment of long term anestrous sows with estradiol benzoate: Response of serum LH and occurrence of estrus. Theriogenology 20:499-507, 1983.

11. Kirkwood RN, Lapwood KR, Smith WC, Moller K, Garrick DJ. Effects of oestradiol benzoate treatment on the reproductive performance and endocrine status of sows after lactations of 10 or 35 days. J Reprod Fert 72:329-337, 1984.

12. Clark JR, First NL, Chapman AB, Casida, LE. Ovarian follicular development during the estrous cycle in gilts following electrocautery of follicles. J Anim Sci 41:1105. $1111,1975$.

13. Dailey RA, Clark JR, Staigmiller RB, First NL, Chapman AB, Casida, LE. Growth of new follicles following electrocautery in four genetic groups of swine. J Anim Sci 43:175-183, 1976.

14. Snedecor GW, Cochran WG. Statistical Methods (6th Ed.) Iowa State University Press, 1967.

15. SAS Institute, Inc. SAS Users Guide: Statistics, 1982 Edition. SAS Institute, Inc., Cary, NC, 1982.

16. Kunavongkrit A, Einarsson S, Settergren I. Follicular development in primiparous lactating sows. Anim Reprod Sci 5:47.56, 1982.

17. Campbell CS, Schwartz, NB. Time course of serum FSH suppression in ovariectomized rats injected with porcine follicular fluid (folliculostatin): effect of estradiol treatment. Biol Reprod 20:1093-1098, 1979.

18. Elsaesser F, Parvizi N. Partial recovery of the stimulatory oestrogen feedback action on LH release during late lactation in the pig. J Reprod Fert 59:63-67, 1980.

19. Edwards S, Foxcroft GR. Response of sows to oestradiol benzoate treatment after weaning at two stages of lactation. J Reprod Fert 67:173-180, 1983. 